\title{
'Old Habits Die Hard' - Reflections on the Scope of the Royal Prerogative Following Turp v Canada (Minister of Justice)
}

\author{
Jarrad Harvey*
}

\section{Introduction}

In Turp v Canada (Minister of Justice), ${ }^{1}$ politician Daniel Turp MP sought judicial review in the Federal Court of Canada of the Canadian Government's decision to withdraw from the Kyoto Protocol to the United Nations Framework Convention on Climate Change. ${ }^{2}$

The case is noteworthy as it contemplates the way countries should legislate their international legal commitments. It also reflects the historical tension between decision-making pursuant to the royal prerogative and the desire for open government and environmental protection. While the case largely reaffirms settled law, particularly in relation to the royal prerogative, it makes a case for the need to better address the tension that lies between the entrenched exercise of the royal prerogative and the desire for accountable and transparent government decision-making, especially in the face of sensitive, international issues like environmental protection.

This case note will consider: (ii) the background to Turp; (iii) what the court said; (iv) an analysis of the existing law; (v) the Federal Court's reasoning and a critique; and (vi) the decision's implications. In (vii), some brief concluding remarks will be offered.

\section{Background}

The United Nations Framework Convention on Climate Change was adopted on 9 May 1992 and was heralded as one of the first international action plans to combat climate change. ${ }^{3}$ On 11 December 1997, the Kyoto Protocol to the UNFCCC was adopted which operationalised the objectives of the UNFCCC by stipulating specific targets for the reduction of greenhouse gas emissions. ${ }^{4}$

The Canadian Government signed the Protocol on 29 April 1998, committing to reduce its emissions by 6 per cent below 1990 levels. ${ }^{5}$ Canada's Kyoto Protocol Implementation Act ${ }^{6}$ entered into force on 22 June 2007.7

Disenchanted by the Protocol's supposed ineffectiveness in combating climate change, ${ }^{8}$ along with evidence of the Protocol's high cost to Canadian tax-payers, ${ }^{9}$ the Canadian Minister of Foreign Affairs, John Baird, following cabinet discussion, communicated to the United Nations Secretary-General on 15 December 2011, the Canadian Government's decision to withdraw from the Protocol and UNFCCC. ${ }^{10}$ Canada's withdrawal took effect a year to the day later, ${ }^{11}$ following the repeal of the KPIA in June $2012 .{ }^{12}$ 
Daniel Turp MP filed an application for judicial review of the Canadian Government's decision in the Federal Court of Canada on 13 January $2012 .{ }^{13}$ The hearing was held in Montréal six months later. ${ }^{14}$

\section{What the Court Decided}

The applicant, Daniel Turp MP, a former politician in Quebec, argued that the Canadian Government's decision to withdraw from the Protocol was "illegal, null, and void"15 as it:

1. violated the KPIA and thus the rule of law;

2. violated the principle of the separation of powers; and

3. violated the democratic principle. ${ }^{16}$

Sitting alone, Justice Simon Noël dismissed all three of these arguments. ${ }^{17}$

\section{Existing Law}

Justice Noël first examined whether the KPIA imposed justiciable duties on the Canadian Government; that is, whether the government's decisions were reviewable by a court of law.

Justice Noël considered the case of Friends of the Earth $v$ Canada (Governor in Council). ${ }^{18}$ In that case, Friends of the Earth - Les Ami(e)s de la Terre, an international network of environmental organisations, alleged that the Minister of the Environment and the Governor in Council failed to fulfil duties imposed on them by virtue of sections 5, 7, 8 and 9 of the KPIA. ${ }^{19}$ In that case, Justice Robert Barnes observed that justiciability is a matter of statutory interpretation; that is, did Parliament intend to make the duties imposed by the KPIA justiciable? ${ }^{20}$ Justice Barnes concluded that while the KPIA "contemplates Parliamentary and public accountability", there must be an express and clearly-worded intention by parliament to render Canada's Protocol commitments justiciable. ${ }^{21}$ Justice Barnes continued that government decision-making regarding Protocol compliance was excluded from judicial review, instead replaced by a "comprehensive system of public and Parliamentary accountabil- ity."22 The Federal Court of Appeal upheld Barnes J's decision. ${ }^{23}$

Justice Noël then went on to consider the first appeal point; that is, did the government's withdrawal from the Protocol violate the rule of law? ${ }^{24}$ The judge considered various cases affirming that issues relating to Canada's negotiation and compliance with treaties will be decided by the executive exercising the royal prerogative. ${ }^{25}$ Justice Noël held that it was settled law that a "decision made in the exercise of prerogative powers would not be justiciable". ${ }^{26}$

Furthermore, responding to the submission by Turp that the royal prerogative could be abolished or limited by legislation, ${ }^{27}$ Noël J recalled earlier judgments which held that government decision-making concerning Protocol commitments was shielded from judicial review. ${ }^{28}$ In one of those cases, Friends of the Earth, the court commented that the royal prerogative could only be abrogated by a mandatory provision conveying such an intent; that is, to limit the scope of the royal prerogative. ${ }^{29}$

Justice Noël then considered whether the royal prerogative could be abrogated by necessary implication, as opposed to being constrained by an express legislative provision. ${ }^{30}$

Justice Noël considered the case of Ross River Dena Council Band $v$ Canada, ${ }^{31}$ where the Federal Court of Appeal considered whether a statutory provision limited the scope of the royal prerogative to set aside land for Indian reserves. ${ }^{32}$ In that case, the Ross River Band of Indians sought clarification as to whether the land their village in the Yukon had occupied since the 1950s was a reserve for the purposes of claiming an exemption from taxes that would otherwise have to be paid on tobacco products sold in the village.

In Ross River, the court was divided as to whether the royal prerogative could be abrogated by "necessary implication" as opposed to being abrogated or constrained by an express, legislative provision. When considering the meaning of necessary implication, the court opted for the definition proposed by Australian jurist and parliamentarian, H.V. Evatt, who argued that: 
[w] here Parliament provides by statute for powers previously within the Prerogative being exercised subject to conditions and limitations contained in the statute, there is an implied intention on the part of Parliament that those powers can only be exercised in accordance with the statute. ${ }^{33}$

Justices Bastarache, McLachlin and L'HeureuxDubé found that an Act of Parliament did not have the effect of limiting the powers exercised by the prerogative to designate land as a reserve, ${ }^{34}$ while Justices Gonthier, Iacobucci, Major, Binnie, Arbour and LeBel found that although the land was set aside for the use of the Ross River Band, and the prerogative to assign reserve-status to land had been "limited to some degree", there was still a clear absence of intention by the persons authorised to bind the Crown to designate the land as a reserve. ${ }^{35}$

In the case at bar, this analysis by the judges in Ross River led Noël J to conclude that the KPIA contained no express provision, nor was there a 'necessary implication' that the statute would limit the application of the royal prerogative to withdraw from the Protocol. ${ }^{36}$

Justice Noël then examined the relevant law concerning the second appeal point; that is, did the government's withdrawal from the Protocol violate the separation of powers? ${ }^{37}$ Rather than exploring the argument that the executive interfered with the legislature's constitutional privilege to pass and repeal laws, ${ }^{38}$ Noël J simply relied on various statements in Operation Dismantle, Blanco and Chrétien taken to conclude that the executive could exercise the royal prerogative to withdraw from the treaty; $; 9$ a decision that would not be justiciable. Justice Noël also cited Friends of the Earth - authority for the proposition that government decisionmaking regarding Protocol compliance is equally non-justiciable. ${ }^{40}$

Finally, regarding the question of whether withdrawing from the Protocol violated the democratic principle, ${ }^{41}$ Noël J's legal analysis was limited to a definition of the democratic principle. ${ }^{42}$ In any event, the judge concluded that the democratic principle was not violated. ${ }^{43}$

\section{The Court's Reasoning and Critique}

In this section, the decision of Noël J will be revisited and critiqued where appropriate.

\section{A Jurisdiction of the Federal Court}

As a preliminary note, the Canadian Government submitted that the FederalCourt of Canada should refuse to rule on this case as the only possible order it could make - a statement of illegality - would be of limited effectiveness. ${ }^{44}$ Justice Noël chided the government, explaining that a statement of illegality plays an indispensable role in scrutinising government power in the public interest. ${ }^{45}$ Further, the judge understandably baulked at the suggestion that the judiciary is limited when it comes to reviewing executive decision-making. Canada's contention arguably misunderstood the court's judicial review function as a necessary check on government power. ${ }^{46}$ On the contrary, as authors like Andrew Banfield and Greg Flynn have argued, Canadian courts in recent years have adopted an enlarged role in the judicial review of executive decisionmaking, serving "both as a primary vehicle and a willing actor to intervene in the policies of the federal government." ${ }^{77}$

\section{$\mathrm{B}$ The rule of law argument}

Turp's first argument was that the withdrawal from the Protocol violated the KPIA and the rule of law. ${ }^{48}$ The rule of law posits that everyone, including citizens and government bodies alike, are bound by a state's laws. Protecting the rule of law is achieved when laws are drafted in a clear, predictable and accessible manner, and when they are publically-adjudicated in courts. ${ }^{49}$

In Turp, Justice Noël promptly noted that executive decision-making relating to the decision to conclude or withdraw from a treaty was protected by the royal prerogative. ${ }^{50}$ Decisions made in exercise of the royal prerogative are not justiciable meaning that such decisions cannot be reviewed by a court. ${ }^{51}$ Further, Noël J held that a court could not question the reasonableness of the government's response to Canada's Protocol commitments, ${ }^{52}$ nor were decisions made under 
the KPIA reviewable regarding "issues of substantive Kyoto compliance". ${ }^{53}$

While judicial activism in this area would no doubt have proven difficult given the royal prerogative's entrenched historical status, ${ }^{54}$ Noël J's mere citing of the law, divorced from any exploration of Turp's submissions or wider discussion of policy, renders his approach as unsympathetic to the public interest of having an open government. Regardless, this is a principled conclusion given the strength of precedent in this area, though Noël J's decision would have benefited from a wider examination of surrounding policy issues. $^{55}$

Notwithstanding his decision, Noël J conceded that the royal prerogative could be abolished or limited by a legislative provision, such as that found within the KPIA. ${ }^{56}$ This followed Turp's argument that the royal prerogative had been withdrawn by necessary implication. ${ }^{57}$ However, Noël J held that the KPIA did not contain an express or implied provision that restricted the exercise of the royal prerogative. ${ }^{58}$ In any event, Noël J recalled Article 27 of the Kyoto Protocol which permitted the Canadian Government to withdraw from the Protocol and UNFCCC. ${ }^{59}$ Thus, the government's decision to withdraw from the Protocol did not violate the KPIA or the rule of law. ${ }^{60}$

Although Noël J's reasoning is logical, the judge failed to adequately explore the argument that sections 3 and 4 of the KPIA, and the fact that the KPIA bound the Crown, withdrew or limited the royal prerogative. ${ }^{61}$ This would have been a welcome analysis adding to the limited jurisprudence of cases considering when an Act of Parliament will implicitly constrain the use of the royal prerogative. ${ }^{62}$ While the rule of law as a doctrine is well-entrenched, Canadian courts have exercised circumspection when considering when and to what extent legislation limits the scope of the royal prerogative. Indeed, this is an issue deserving of separate analysis.

As such, Noël J concluded that the government's decision to withdraw from the Protocol did not violate the KPIA or the rule of law.

\section{The separation of powers argument}

Turp's second submission was that the withdrawal from the Protocol violated the principle of the separation of powers as it did not have regard for the KPIA and legislature. ${ }^{63}$ The separation of powers is the principle that government operations be divided into three arms: the legislative arm which creates laws, the executive arm which operationalises laws, and the judicial arm which interprets laws. ${ }^{64}$

Justice Noël held that since the government's decision to withdraw from the Protocol was not limited by the KPIA but instead decided by invoking the royal prerogative, the government's decision to withdraw from the Protocol did not offend the separation of powers principle. ${ }^{65}$ In any event, Noël J held that both the government's withdrawal from the Protocol and questions of treaty compliance were not justiciable. ${ }^{66}$ Thus, Noël J held that the government's withdrawal from the Protocol did not contravene the separation of powers. ${ }^{67}$

While earlier criticisms are relevant here, such as a missed opportunity for Noël J to consider the policy reasons behind Turp's submissions, the fact that this and the final submission were dealt with summarily are illustrative of the entrenched law underpinning the royal prerogative. ${ }^{68}$ Nevertheless, it might have been useful for Noël J to clarify the relationship between the separation of powers and the royal prerogative.

\section{The democratic principle argument}

Turp's final argument was that the withdrawal from the Protocol violated the democratic principle. ${ }^{69}$

Turp argued that just as the ratification of the Protocol followed a public discussion in the House of Commons resulting in the passing of a motion in favour of ratification, the government's decision to withdraw from the treaty ought to have been subject to similar parliamentary debate. ${ }^{70}$ Yet Noël J observed that the motion that asked the House of Commons to ratify the Protocol still recognised, at the time, the power of the executive to conclude or withdraw from 
treaties without the need to consult the House of Commons. ${ }^{71}$

Justice Noël rejected this third argument without any real exploration of Turp's submission; another missed opportunity for clarification especially given the importance of concepts like the democratic principle and open government in the common law tradition. ${ }^{72}$

Thus, Noël J concluded that the government did not have to consult the House of Commons before withdrawing from the Protocol. ${ }^{73}$ Indeed, he observed that it was up to Parliament to pass a law to compel consultation between the executive and House of Commons. ${ }^{74}$

On a separate but related point, regarding the argument that the provinces ought to have been consulted, Noël J observed that the provinces, and not Turp, would have been better placed to argue this point. ${ }^{75}$

Consequently, the court held that the government's decision to withdraw from the Protocol did not violate the democratic principle. ${ }^{76}$

\section{Implications of the Decision}

While Turp overwhelmingly affirms settled law regarding the exercise of the royal prerogative, it is still noteworthy for various reasons.

First, Turp serves as a guide to municipal governments on how not to implement international legal obligations. The Canadian Government was under an obligation to devise regulations "to fully meet ... [Canada's] obligations" under the Protocol..$^{77}$ Yet, when the Canadian Government withdrew from the Protocol - an unreviewable decision ${ }^{78}$ - the legislation was rendered meaningless as Canada no longer had any Protocol obligations for which to issue regulations.

Consequently, prudent governments would be well-advised to follow, say, the Australian model of directly legislating commitments to the Protocol within domestic legislation. ${ }^{79}$ In that model, even if a government withdraws from a relevant treaty, the executive would have to appeal to parliament to repeal the domestically incorporated law. Debating such sensitive, international environmental issues in parliament by elected members imposes a layer of accountability on government which is not as incumbent in cabinet decision-making exercising the royal prerogative.

Another implication at the national level relates to the assurances of having an accountable government. Overwhelmingly, the decision in Turp consolidates the already entrenched judicial position favouring the exercise of the royal prerogative in common law countries. ${ }^{80}$ Continued judicial parsimony in this area may have the effect of thwarting attempts to make the exercise of executive power more transparent and accountable to government bodies and public expectations. Indeed, in recent years there has been an increasing amount of criticism directed against governments of common law countries that make unpopular decisions using the royal prerogative. ${ }^{81}$

It may be that for issues relating to a countries' international environmental commitments, in the face of something so resolute, like the exercise of the royal prerogative, dissatisfied citizens should resort to putting political pressure on the government of the day in the hope that popular support may sway the outcome of a decision such as that relating to the withdrawal from a critical international environmental treaty. Though executive decision-making informed by the royal prerogative may be immune from judicial review, government decisions are not immunised from vocal populations disenchanted with their elected government's actions.

Further, as Noël J affirmed, the scope of the royal prerogative can be limited expressly by parliament if it wishes to make cabinet decisionmaking more accountable and transparent. That said, it is unlikely that the government of the day would support legislation restricting the cabinet's capacity to make largely unreviewable decisions in the national interest. Notwithstanding that conclusion, clarity in the area of the validity of expressly legislated restrictions of the royal prerogative means that such provisions may be a way forward for progressive governments to 
enhance the transparency and accountability of cabinet decision-making.

On a wider international level, Turp further raises the issue of the need for states to address the challenge of countries maintaining a unified commitment to their international legal obligations. This can be particularly difficult when the need for environmental protection intersects with issues of sovereignty and national self-interest. $^{82}$

Broadly-speaking, our current international legal system is comprised of countries willing to volunteer their matters to international and regional legal architectures, such as treaties and courts. The Canadian Government's decision to withdraw from the Kyoto Protocol risks the erosion of a uniform, environmental legal framework. Such international disunity may also result in further environmental damage as issues like environmental protection are sidelined by issues relating to sovereignty and self-interest.

Finally, following the example of Canada, another implication may be that other countries, especially common law countries where the entry into treaties is a decision for the executive, may be more willing to abandon their international legal commitments under multilateral environmental agreements (MEAs) with the previously foretold risks to the international legal system and, in turn, environmental protection.

\section{Moving Forward}

While Turp is undoubtedly a product of reasoned and logical judicial decision-making, the decision makes a case for the need to better reconcile the tension that lies between the entrenched status of the royal prerogative and the expectation of accountable government decision-making, particularly when the exercise of the prerogative affects sensitive, international issues like environmental protection.

A possible solution to this dilemma would be for municipal parliaments, heeding the decision in Turp, to expressly legislate against the executive withdrawing from treaties such as those aimed at environmental protection. Had the
KPIA been drafted in this manner, the result in Turp would undoubtedly be different.

\section{Endnotes}

* BBA, LLB (Hons 1), Macquarie University; postgraduate student in the Department of Government and International Relations, The University of Sydney. The views in this article are my own and do not represent the views of any third parties.

12012 FC 893, [2012] FCJ no 944 (QL) [Turp].

2 Kyoto Protocol to the United Nations Framework Convention on Climate Change, 11 December 1997, 2303 UNTS 148 (entered into force 16 February 2005) [Protocol].

3 United Nations Framework Convention on Climate Change, 9 May 1992, 1771 UNTS 107 (entered into force 21 March 1994) [UNFCCC]. Article 2 of the UNFCCC stipulates the Convention's objectives which are to stabilise the amount of greenhouse gas in the atmosphere, to ensure food production is not threatened, and to allow for the continuation of economic development in a sustainable manner; Turp, supra note 1 at para 2.

4 Supra note 2. Of the many obligations set down by the Protocol, Article 3 encourages signatories to reduce their overall greenhouse gas emissions by at least 5 per cent below equivalent 1990 levels; Turp, supra note 1 at para 3 .

5 Turp, supra note 1 at para 4.

6 Kyoto Protocol Implementation Act, SC 2007, c 30, as repealed by Jobs, Growth and Long-term Prosperity Act, SC 2012, c 19 (['KPIA]'); see also Turp, supra note 1 at para 21. Under the KPIA, the government must prepare a climate change plan (section 5), make, amend or repeal necessary regulations to ensure that Canada fully meets its obligations under the Protocol (section 7), and prepare a statement indicating expected reductions in greenhouse gas emissions for each year up to and including 2012 (section 9).; Environment Canada, A Climate Change Plan for the Purposes of the Kyoto Protocol Implementation Act - 2007 (Gatineau, Que: Environment Canada, 2007) at v-vi. However, rather than over-regulating, many details of how the Canadian Government would reach tangible reduction targets were left to the wide discretion of the Governor in Council to make, amend or repeal regulations (sections 6-8).

7 Turp, supra note 1 at para 6. 
8 See generally British Broadcasting Corporation, "Canada to withdraw from Kyoto Protocol", $B B C$ News - US and Canada (13 December 2011) online: BBC News <http://www.bbc.co.uk/ news/world-us-canada-16151310> [“Canada to withdraw"]. Current Canadian Environment Minister Peter Kent reported then that the Protocol "does not represent a way forward for Canada", and feared that Canada would "face crippling fines for failing to meet its targets"; see also Louis Charles Chambers, Tort Law, Climate and Private Nuisance (Honours thesis, The University of Otago, 2012), online: (2012) OYLR at 6 <www.otago.ac.nz/law/ research/journals $>$.

9 "Canada to withdraw", supra note 8. The Canadian Environment Minister further feared that that the Protocol would cost Canada US\$13.6 billion, translating to a cost of US\$1600 per Canadian family.

10 Turp, supra note 1 at para 11.

11 Ibid.

12 Jobs, Growth and Long-term Prosperity Act, SC 2012, c 19; Turp, supra note 1 at para 12.

13 Turp, supra note 1 at para 12.

14 Ibid.

15 Ibid at para13.

16 Ibid at paras $13,15$.

17 Ibid at paras 26, 28, 31-32.

182008 FC 1183, [2009] 3 FCR 201 [Friends of the Earth].

19 Turp, supra note 1 at para 7.

20 Friends of the Earth, supra note 18 at para 31; Turp, supra note 1 at para 7 .

21 Friends of the Earth, supra note 18 at para 42; Turp, supra note 1 at para 8 .

22 Friends of the Earth, supra note 18 at para 44; Turp, supra note 1 at para 8 .

23 Friends of the Earth $v$ Canada (Governor in Council), 2009 FCA 297, 313 DLR (4th) 767; Turp, supra note 1 at para 9.

24 Turp, supra note 1 at para 18.

25 Ibid. Justice Noël cited Operation Dismantle Inc $v$ Canada, [1985] 1 SCR 441, [1985] SCJ no 22 (QL) [Operation Dismantle], Blanco v Canada, [2003] FCJ no 355 (QL) , 231 FTR 3, [Blanco], Turp v Canada (Prime Minister) [2003] FCJ no 423 (QL), 237 FTR 248 [Turp v Canada (Prime Minister)]; Turp v Chrétien [2003] JQ 7019 (available on QL) [Chrétien].

26 Turp, supra note 1 at para 18. .

27 Ibid at para 19. Turp relied on Attorney General (On behalf of His Majesty) $v$ De Keyser's Royal Hotel Ltd [1920] AC 580 (HL).
28 Turp, supra note 1 at paras 22-24. Justice Noël citing Friends of the Earth, supra note 18 at para 44.

29 Friends of the Earth, supra note 18 at 44; Turp, supra note 1 at para 22. .

30 Turp, supra note 1 at para 23.

312002 SCC 54, [2002] 2 SCR 816 [Ross River].

32 Turp, supra note 1 at para 24.

33 Ross River, supra note 31 at para 4.

34 Ibid at para 2.

35 Ibid at paras 58 and 78.

36 Turp, supra note 1 at para 25.

37 Ibid at para 27.

38 Ibid.

39 Ibid at para 28.

40 Ibid.

41 Ibid at para 29.

42 Ibid. Justice Noël cited the Applicant's Memorandum at paragraph 48 which defined the democratic principle as "an obligation to encourage public discussion on all issues of public interest and consult the House of Commons as it is an essential element of our system of representative government."

43 Ibid at para 31.

44 Ibid at para 17.

45 Ibid.

46 See, eg, Peter Butt, ed, Concise Australian Legal Dictionary (Chatswood, New South Wales: LexisNexis Butterworths, 2004) sub verbo "judicial review". Judicial review is defined as "the determination by courts of the legality of exercises of power."

47 See, eg, Andrew Banfield and Greg Flynn, "Activism or Democracy? Judicial Review of Prerogative Powers and Executive Action", Parl. Aff., Advance Access published 3 July 2013, doi:10.1093/pa/ gst009 at 17.

48 Turp, supra note 1 at para 18.

49 "Rule of law", online: Australian Government Attorney-General's Department <http://www. ag.gov.au/About/Pages/Ruleoflaw.aspx $>$.

50 Turp, supra note 1 at para 18. Justice Noël cited a number of authors supporting this proposition including: A E Gotlieb, Canadian Treaty-Making (Toronto: Butterworths, 1968) at 4, 14; and John H Currie, Craig Forcese \& Valerie Oosterveld, International Law: Doctrine, Practice, and Theory (Toronto: Irwin Law, 2007) at 54-56.

51 Ibid at para 18.

52 Ibid at para 22. Justice Noël citing Friends of the Earth, supra note 18 at para 46.

53 Ibid at para 22. Justice Noël citing Friends of the Earth, supra note 18 at para 44. 
54 Claire Nielsen, "The Executive Treaty-making Prerogative: A History and Critique" (2007) 4 NZYIL 173 at 179. Nielsen remarks that the royal prerogative enjoys "a long and chequered history ... notoriously difficult to define ... and tied to notions of royal authority."

55 Ibid; See, eg, Laura Payton, "Federal Court backs government over Kyoto pullout", CBC News (17 July 2012) online: CBC News <http://www.cbc.ca/ news/canada/story/2012/07/17/pol-kyoto-pullout-valid.html $>$. Payton quoted academic Emmett MacFarlane, who, on the topic of conservative judicial stances toward the exercise of the royal prerogative, commented: "[i]t would have been surprising if the court had limited the royal prerogative ... The courts have always been very reluctant to delve into matters dealing with the royal prerogative powers."

56 Turp, supra note 1 at para 19.

57 Ibid at para 20. Justice Noël referred to the Applicant's Memorandum at paragraph 27 which argued that the royal prerogative was limited by necessary implication as the KPIA "occupied the entire field of the Protocol", as reflected in sections 3 and 4 and in the fact that the Act was binding upon the Crown.

58 Ibid at para 25.

59 Ibid.

60 Ibid at para 26.

61 Ibid at para 20.

62 Ibid at para 24. Justice Noël J cited the decision of Ross River, supra note 31 at para 4. In that case, the Supreme Court of Canada admitted that "it is less certain whether in Canada the prerogative may be abolished or limited by necessary implication."

63 Ibid at para 27.

64 "Separation of Powers: Doctrine and Practice", online: Parliament of New South Wales <http:// www.parliament.nsw.gov.au/prod/parlment/ publications.nsf/key/SeparationofPowers $>$.

65 Turp, supra note 1 at para 28.

$66 \mathrm{Ibid}$. Justice Noël cited the decisions of Operation Dismantle, Blanco, Turp v Canada (Prime Minister) and Chrétien, supra note 25, in support of this conclusion. Justice Noël cited Friends of the Earth, supra note 18 in support of this second conclusion.

67 Ibid at para 28.

68 See, eg, Nielsen, supra note 54.

69 Turp, supra note 1 at para 29; See supra note 42.

70 Turp, supra note 1 at para 30.

71 Ibid at para 31.

72 See, eg, Nicholas Aroney, "Justice McHugh, Representative Government and the Elimination of Balancing" (2006) 28:3 Sydney L Rev 505 at
506. For example, Aroney describes representative government as "constitutionally prescribed."

73 Turp, supra note 1 at para 31.

74 Ibid.

75 Ibid at para 32.

76 Ibid at para 31.

77 Ibid at para 21.

78 Ibid at para 22. Noël J citing Friends of the Earth, supra note 18 at para 44.

79 Clean Energy Act 2011 (Cth), section 4. Section 4, "Simplified Outline", provides a useful overview of the Act's mechanisms to put a price on greenhouse gas emissions pursuant to Australia's Protocol commitments.

80 Payton, supra note 55.

81 See, eg, George Williams, "The Power to Go to War: Australia in Iraq" (2004) 15 PLR at 5. In this article, Williams criticises the then Australian Government's decision to declare war on Iraq - a decision made without consulting parliament, but which was exercised using the royal prerogative by the cabinet of the in-power Liberal government. Williams recommends that the prerogative power of the Commonwealth of Australia should be amended in this area by legislation, thus improving accountability and transparency in executive decision-making.

82 But see William R Moomaw, "International Environmental Policy and the Softening of Sovereignty" (1997) 21:2 Fletcher F. Wld. Aff. 7 at 14. Moomaw, citing Evgeunij Velikhov, comments that "addressing global environmental problems would require nations to relinquish some sovereignty." 